\title{
"Experimental Study on Fly Ash based Geopolymer Concrete with Replacement of Sand by GBS"
}

\author{
Adanagouda*, Pampapathi G S**, A.Varun***, Ramya Madagiri**** \\ Merugu Keerthan***** \\ *(Assistant Professor, Dept. of Civil Engineering, RYMEC Ballari, Karnataka, India) \\ ** (Final Year, BE Student, Dept. of Civil Engineering, RYMEC Ballari, Karnataka, India) \\ *** (Final Year, BE Student, Dept. of Civil Engineering, RYMEC Ballari, Karnataka, India) \\ **** (Final Year, BE Student, Dept. of Civil Engineering, RYMEC Ballari, Karnataka, India) \\ ****** (Final Year, BE Student, Dept. of Civil Engineering, RYMEC Ballari, Karnataka, India)
}

\begin{abstract}
The objective of this research work was to produce a carbon dioxide emission free cementitious material. The geopolymer concrete is totally cement free concrete. In this present study the main limitations of fly ash based geopolymer concrete are slow setting of concrete at ambient temperature and Granulated Blast Furnace Slag (GBS) as replacement for natural sand. Fly ash and alkaline activator undergo geo polymerization process to produce alumina silicate gel. Alkaline solution used in the present study for the combination of sodium hydroxide and sodium silicate with a ratio of 1:2.5. A 13 Molarity solution was taken to prepare the mix and maintaining the alkaline binder ratio as 0.40. The solution for different mix Id i.e. G0S100, G10S90, G20S80, G30S70, G40S60, G50S50, G60S40, G70S30, G80S20, G90S10, and G100S0 (Where G and S are, respectively, GBS and Sand and the numerical value indicates the percentage of replacement of natural sand by GBS). The cube specimens are taken of size $100 \mathrm{~mm}$ x $100 \mathrm{~mm}$ x $100 \mathrm{~mm}$. Ambient curing of concrete at room temperature was adopted. In total 66 cubes were cast for different mix Id and the cube specimens are tested for their compressive strength at age of 7 days and 28 days respectively. The strength of geopolymer concrete was increased with increase in percentage of GBS in a mix. It was observed that the mix Id G100S0 gave maximum compressive strength of $74.33 \mathrm{~N} / \mathrm{mm} 2$. Also the splitting tensile strength and flexural strength for the mix G100S0 was done. Geopolymer concrete is revolutionary sustainable that will pave the way for green building.

Keywords: Geopolymer concrete, Fly ash, GBS, Supper plasticizer, Ambient curing.
\end{abstract}

\section{INTRODUCTION}

The major problem that the world is facing today is the environmental pollution. Concrete is one of the most widely used construction material. Portland cement production is a major contributor to $\mathrm{CO} 2$ emissions. The global warming is caused by the emission of greenhouse gases, such as $\mathrm{CO} 2$ into the atmosphere by human activities. Among the greenhouse gases, $\mathrm{CO} 2$ contributes about $65 \%$ of global warming. Many efforts are being made in order to reduce the use of Portland cement in concrete.

\section{LITERATURES ON GEOPOLYMER CONCRETE.}

Matghew Sudhakar and Natarajan presented the increase of GGBS content, Compressive Strength is gradually increases .in this Coal Ash and GGBS Combination is taken along with $15 \mathrm{M}$ Alkaline Solution and total replacement of about $30 \%$ is taken into consideration and Higher Compressive Strength up to $57 \mathrm{Mpa}$ is achieved .However the cost of GGBS added Geopolymer is 7\% Higher than OPC but when we Consider Strength aspect, it is almost 3 times than
$\mathrm{OPC}$ at 7 days.

Supraja .V, M. KantaRao presented a study of geopolymer concrete, the Portland cement is fully replaced with GGBS and alkaline liquids (sodium hydroxide and sodium silicate) are used for the binding of materials. Different molarities of sodium hydroxide solutions i.e. $3 \mathrm{M}, 5 \mathrm{M}, 7 \mathrm{M}$ and $9 \mathrm{M}$ are considered. The strength of geopolymer increases with increase of molarity of sodium hydroxide.

Ganapati Naidu.etl reported in this paper that an attempt is made to study strength properties of geopolymer concrete using low calcium fly ash replacing with slag in 5 different percentages. Higher concentrations of G.G.B.S (Slag) result in higher compressive strength of geopolymer concrete. $90 \%$ of compressive strength was achieved in 14 days.

Pratap,Krishnan are presented the experimental investigation FLY ASH and BLAST FURNACE SLAG are used in equal proportion (50\% each). The geopolymer concrete gains about $60-70 \%$ of the total compressive strength within 7days.

Quasrawi et al. The slag is used as fine aggregate replacing the sand in the mixes partially or totally. 
Ratios of $0,15,30,50$, and $100 \%$ are used. Best results are obtained for replacement ratios of 30-50\% for tensile strength and $15-30 \%$ for compressive strength.

\section{MATERIALS USED}

a) Fly ash was taken from thermal power plant at KUDITHINI BELLARY THERMAL POWER STATION was used in the investigation. The specific gravity is 2.20 .

b) GBS ash was taken from Jindal Steel plant at Vidynagar; Ballari was used in the investigation. The specific gravity is 2.11 and result of sieve analysis designate that the GBS confirms to zone III c) Fine aggregate: -Locally available sand, free from silt and organic matters was used. The particle size of the sand used in this study was such a way that it passed through $4.75 \mathrm{~mm}$ sieve conforming to zone III. The specific gravity was 2.55 and Fineness modulus was 2.59 .

d) Coarse aggregate: - Crushed granite metal with $60 \%$ passing $20 \mathrm{~mm}$ and retained on $12.5 \mathrm{~mm}$ sieve and $40 \%$ passing $12.5 \mathrm{~mm}$ and retained on $4.75 \mathrm{~mm}$ sieve were used. The weight of coarse aggregate was $60 \%$ of the total aggregate and specific gravity of coarse aggregate was 2.84

e) Super plasticizer: To improve the workability of the mixes, a high range water reducing agent Fosroc conplast SP430 (SNF- Sulphonated Naphthalene Formaldehyde) $2 \%$ of fly ash is used.

f) Alkaline Solutions: The solution of sodium hydroxide and sodium silicate are used as alkaline solutions in the present study. Commercial grade sodium hydroxide in pellets form and sodium silicate solution are used.

\section{Preparation of Alkaline Solutions}

The mixture of sodium silicate solution and sodium hydroxide solution forms the alkaline liquid. A combination of alkaline silicate solution and alkaline hydroxide solution was chosen as the alkaline liquid. In this research work the compressive strength of Geopolymer concrete is examined for the mixes of 13 Molarity of sodium hydroxide. The molecular weight of sodium hydroxide is 40 . To prepare 13 Molarity of solution $520 \mathrm{gm}$ of sodium hydroxide flakes are weighed and they can be dissolved in distilled water to form 1 litre solution has to be prepared 24 hours advance before use. Sodium hydroxide flakes are added slowly to distilled water to prepare 1liter solution.

\section{MIX PROPORTIONS}

The conventional method used in the making of normal concrete is adopted to prepare geopolymer concrete.First, the fine aggregate, coarse aggregate, GBS and fly ash is mixed in dry condition for 3- 4 minutes and then the alkaline solution which is a combination of Sodium hydroxide solution and Sodium silicate solution with a ratio of 1:2.5 and super plasticizer is added to the dry mix. The mixing is done about $6-8$ minutes for proper bonding of all the materials. After the mixing, the specimens are casted by giving proper compaction in three layers.

Table - 1.0 Material requirement for $1 \mathrm{~m}^{3}$.

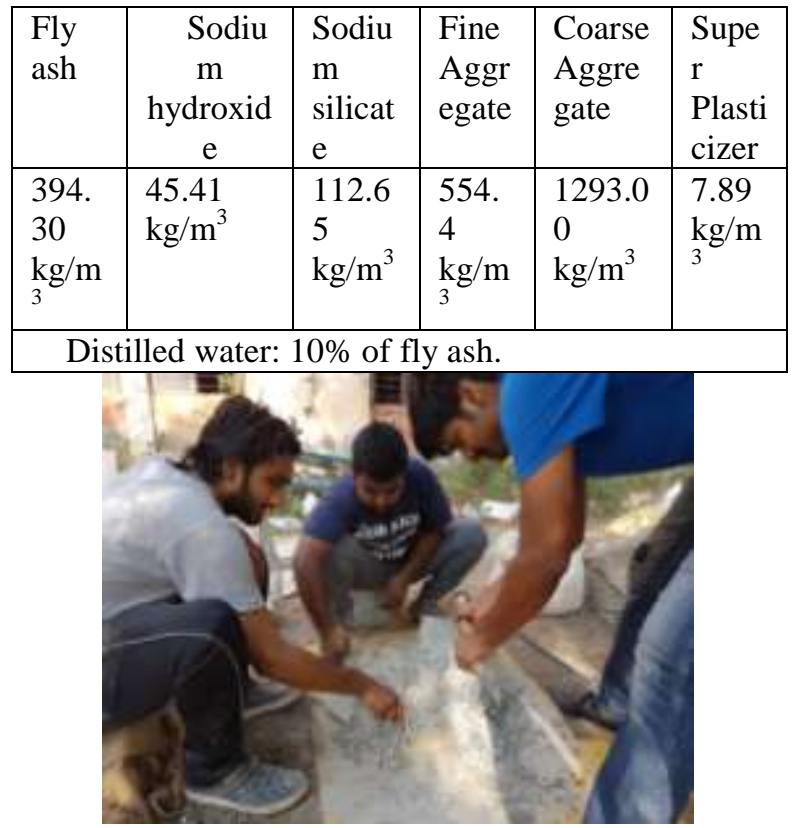

Figure 1.0 Dry mixing process.

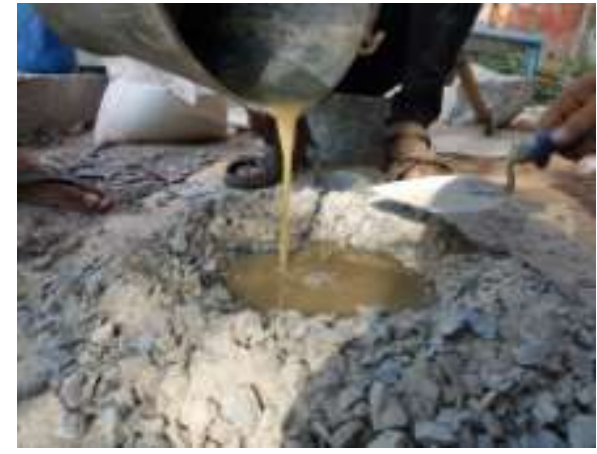

Figure 2.0 Addition of alkaline solution.

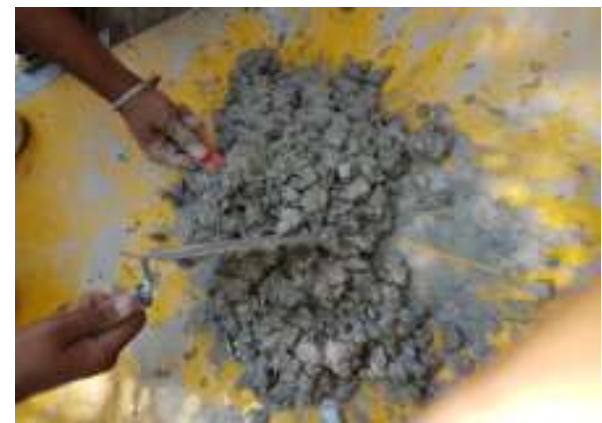

Figure 3.0 Wet mixing process. 


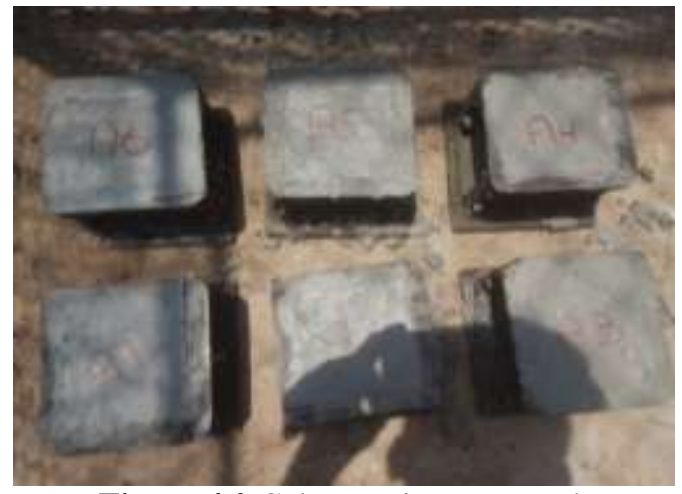

Figure 4.0 Cube specimens casted.

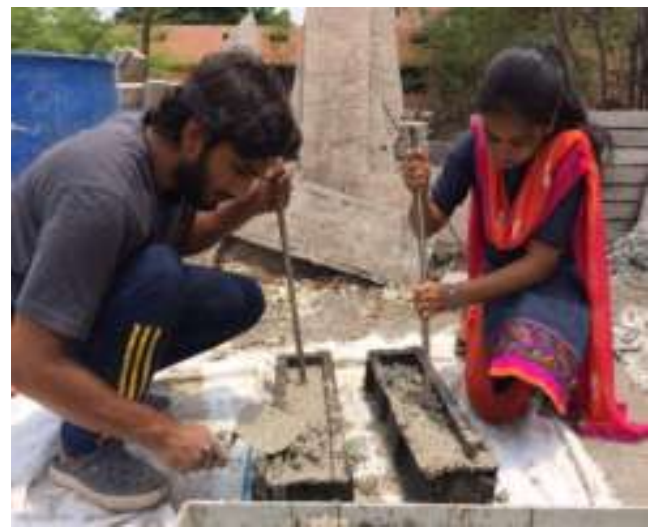

Figure 5.0 Prism specimens casted

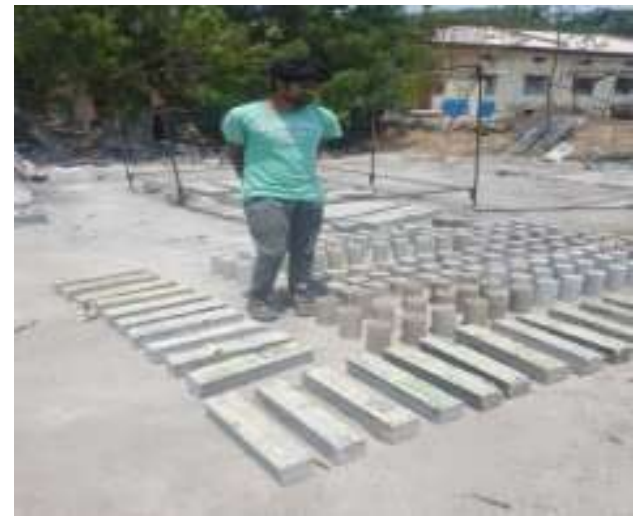

Figure 6.0 Specimens curing in Ambient Temperature.

\section{METHODOLOGY}

During the present study explains about the step by step procedure that is going to be done in the project. The methodology is explained in the figure.7.0

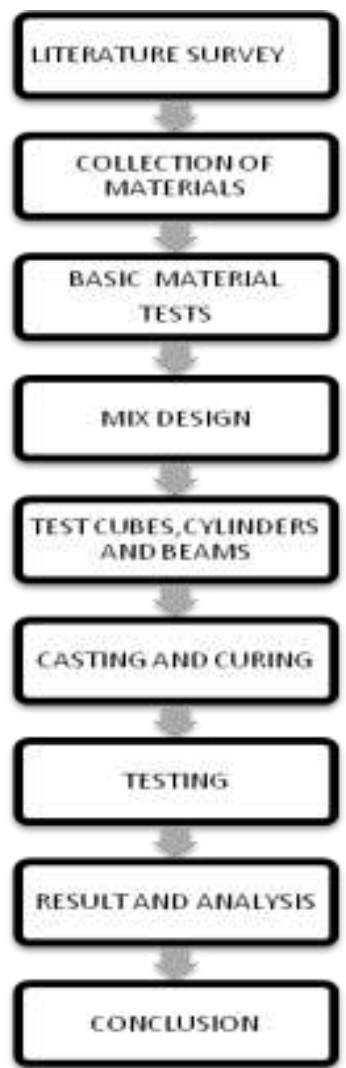

Figure 7.0 Methodology of Geopolymer Concrete.

\section{TEST RESULTS}

The various strength tests that are to be done listed as below.

$>$ Compressive Strength

$>$ Split Tensile Strength

$>$ Flexural Strength

Table.2 Details of Test Specimens

\begin{tabular}{|r||l||c||c||}
\hline $\begin{array}{l}\text { Sl. } \\
\text { No }\end{array}$ & Name of Test & $\begin{array}{l}\text { Size of } \\
\text { Specimen } \\
(\mathrm{mm})\end{array}$ & $\begin{array}{l}\text { Number of } \\
\text { Specimen } \\
\text { casted }\end{array}$ \\
\hline \hline 1. & $\begin{array}{l}\text { Compressive } \\
\text { Strength (P/A) }\end{array}$ & $\begin{array}{c}100 \times 100 \times \\
100\end{array}$ & 66 \\
\hline 2. & $\begin{array}{l}\text { Split Tensile } \\
\text { Strength } \\
(2 \mathrm{P} / \pi \mathrm{LD})\end{array}$ & $100 \times 200$ & 33 \\
\hline \hline 3. & $\begin{array}{l}\text { Flexural } \\
\text { Strength } \\
(\text { PL/bd }\end{array}$ & $\begin{array}{c}500 \times 100 \times \\
100\end{array}$ & 33 \\
\hline \hline \multicolumn{2}{|c|}{ Total } & 132 \\
\hline
\end{tabular}

\section{Compressive Strength Test:}

Concrete cubes are tested in compressive testing machine (200 Tonne capacity) to determine their compressive strength of 3 specimens at the age of 7 days and 28 days of curing. 
Table.3 Average Cube compressive strength results

\begin{tabular}{|c|c|c|}
\hline \multirow{2}{*}{ Mix Id } & \multicolumn{2}{|c|}{$\begin{array}{c}\text { Compressive strength } \\
\left(\mathbf{N} / \mathbf{m m}^{2} \text { ) }\right.\end{array}$} \\
\cline { 2 - 3 } & $\mathbf{7 ~ d a y s}$ & $\mathbf{2 8 ~ d a y s}$ \\
\hline G0 S100 & 33.27 & 39.00 \\
\hline G10 S90 & 42.53 & 44.61 \\
\hline G20 S80 & 43.00 & 47.70 \\
\hline G30 S70 & 45.33 & 48.35 \\
\hline G40 S60 & 46.62 & 49.60 \\
\hline G50 S50 & 46.78 & 51.67 \\
\hline G60 S40 & 47.33 & 57.63 \\
\hline G70 S30 & 49.73 & 59.00 \\
\hline G80 S20 & 50.33 & 60.10 \\
\hline G90 S10 & 61.00 & 63.63 \\
\hline G100 S0 & 66.00 & 74.33 \\
\hline
\end{tabular}

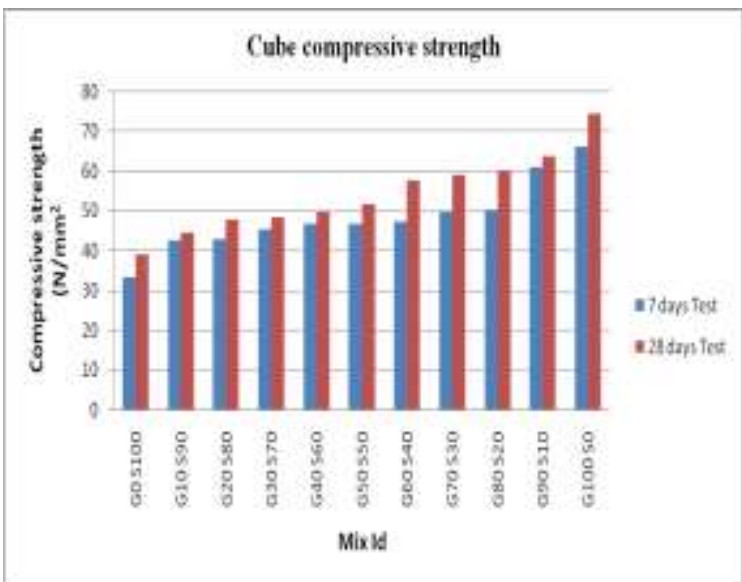

Graph. 1.0 Cube compressive strength.

Split tensile strength test: Tensile strength is one of the basic and important properties of concrete. Size of test sample of $10 \mathrm{~cm}$ diameter, $20 \mathrm{~cm}$ height and $0.3 \mathrm{~cm}$ thick cylindrical mould is used. The compressive testing machine and the load is applied. The load at which the sample in the end fails is noted and split tensile strength is calculated.

Flexural strength test: The prism is generally tested to identify the flexural behavior of the hardened concrete. The test is carried in a universal testing machine of 100T load ability. Standard prism of size $10 \mathrm{~cm} \times 10 \mathrm{~cm} \times 50 \mathrm{~cm}$ were tested under one point loading to study the flexural strength of concrete.

Table. 4 Split Tensile Strength and Flexural Strength results at 28 Days.

\begin{tabular}{|c|c|c|}
\hline \multirow[t]{2}{*}{ Mix Id } & \multicolumn{2}{|c|}{ Strength $\left(\mathbf{N} / \mathbf{m m}^{2}\right)$} \\
\hline & $\begin{array}{c}\text { Split } \\
\text { Tensile }\end{array}$ & $\begin{array}{l}\text { Flexural } \\
\text { Strength }\end{array}$ \\
\hline G0 S100 & 4.77 & 14.26 \\
\hline G10 S90 & 5.09 & 14.56 \\
\hline G20 S80 & 5.13 & 14.56 \\
\hline G30 S70 & 5.19 & 14.62 \\
\hline G40 S60 & 5.27 & 1487 \\
\hline
\end{tabular}

\begin{tabular}{|c|c|c|}
\hline G50 S50 & 5.35 & 14.93 \\
\hline G60 S40 & 5.47 & 15.55 \\
\hline G70 S30 & 5.52 & 15.55 \\
\hline G80 S20 & 5.58 & 15.62 \\
\hline G90 S10 & 5.63 & 16.48 \\
\hline G100 S0 & 5.74 & 16.58 \\
\hline
\end{tabular}

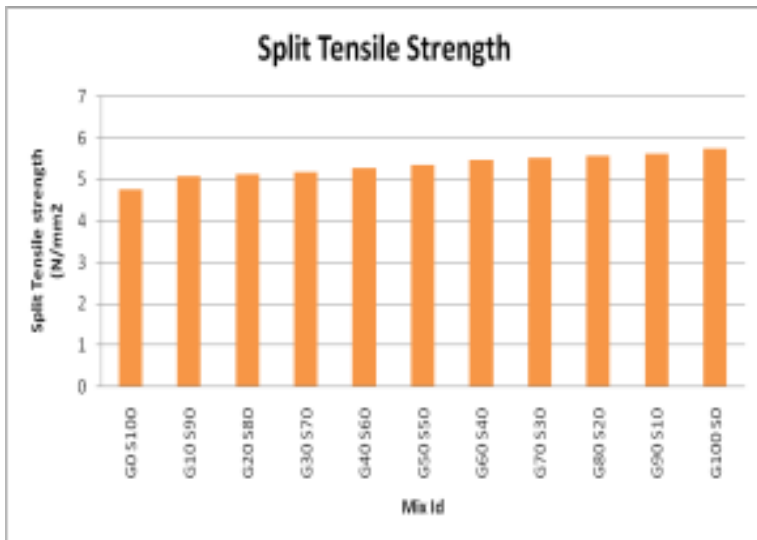

Graph. 2.0 Split Tensile strength.

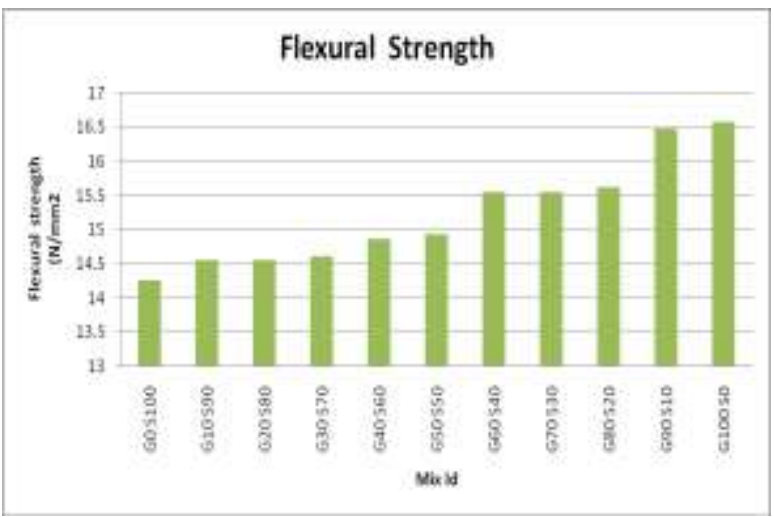

Graph. 3.0 Flexural strength.

\section{CONCLUSIONS}

Based on the results obtained in the experimental investigation, the following conclusions are drawn.

- It was observed that Compressive strength was found maximum for complete replacement of river sand by GBS. The compressive strength increased by $90 \%$ for complete replacement of sand.

- It was observed that Split tensile strength was found maximum for complete replacement of river sand by GBS. The split tensile strength increased by $20 \%$ for complete replacement of sand.

- It was observed that flexural strength was found maximum for complete replacement of river sand by GBS. The flexural strength increased by $16 \%$ for complete replacement of sand.

- The geopolymer concrete gained strength within 24 hours at ambient temperature without water curing. 
- The strength of geopolymer concrete was increased with increase in percentage of GBS in a mix.

\section{Cost Analysis}

Cost analysis for geopolymer concrete and conventional concrete (CC). The cost of the geopolymer concrete is $04 \%$ higher than the conventional concrete.

Table 5.0 Cost Analysis for GBS and CC

\begin{tabular}{|c|c|c|c|c|}
\hline $\begin{array}{l}\text { Sl.N } \\
\text { o }\end{array}$ & Materials & $\begin{array}{l}\text { Cost } \\
(\mathrm{Rs} / \mathrm{K} \\
\mathrm{g})\end{array}$ & $\begin{array}{l}\text { Total } \\
\text { Amount } \\
\text { For GBS } \\
\left(\mathrm{Rs} / \mathrm{m}^{3}\right)\end{array}$ & $\begin{array}{l}\text { Total } \\
\text { Amount } \\
\text { of CC } \\
\left(\mathrm{Rs} / \mathrm{m}^{3}\right) \\
\end{array}$ \\
\hline 1 & Cement & 7.00 & --- & 2765.00 \\
\hline 2 & $\begin{array}{l}\text { Fine } \\
\text { aggregat } \\
\text { es }\end{array}$ & 1.26 & 699.00 & 699.00 \\
\hline 3 & $\begin{array}{l}\text { Coarse } \\
\text { aggregat } \\
\text { es }\end{array}$ & 1.2 & 1551.00 & 1551.00 \\
\hline 4 & GBS & 0.20 & 110.00 & --- \\
\hline 5 & Fly ash & 0.11 & 44.00 & --- \\
\hline 6 & $\mathrm{NaOH}$ & 16.00 & 720.00 & --- \\
\hline 7 & $\mathrm{Na}_{2} \mathrm{SiO}_{3}$ & 18.00 & 2016.00 & --- \\
\hline \multicolumn{3}{|c|}{$\begin{array}{l}\text { TOTAL ( Rs. Per } \\
\text { Cu.mt) }\end{array}$} & 5140.00 & $00^{5015 .}$ \\
\hline
\end{tabular}

\section{ACKNOWLEDGEMENTS}

The authors wish to thank the Management, Principal, Head of Civil Engineering Department and staff of RYM Engineering College Ballari for their support. The authors express their deep and sincere thanks to Mr. Adana Gouda (Asst. Professor, Department of Civil Engineering, RYMEC Ballari) for her tremendous support and valuable guidance from time to time.

\section{REFERENCES}

\section{Journal Papers:}

[1] [1] P. Abhilash, C. Sashidhar, I.V.Ramana Reddy (2016), "Strength properties of Fly ash and GGBS based Geo-polymer Concrete" International Journal of ChemTech Research, Vol.9, No.03 pp 350356, ISSN: 0974-4290

[2] [2] Prasanna, B. Lakshminarayanan, M. Arun Kumar, J.R Dinesh Kumaran (2016), "Flyash based geopolymer concrete using GGBS" International Conference on Current Research in Engineering Science and Technology ,E-ISSN :2348 - 8352.

[3] [3] Gartner E (2004), "Industrially interesting Approaches to Low - CO2 Cements", cement and concrete research, 34(9), $1489-1498$.

[4] [4] Pawan kumar K R, Surendra B, "Study on Strength of Geopolymer concrete with ambient temperature curing and low alkali content", IRJET, Volume: 03 Issue: 05May-2016. Page 1073-1077

[5] [5] Vijai K, Kumutha R and Vishnuram B.G, (2012). "Experimental Investigations on mechanical properties of Geopolymer Concrete composites", Asian journal of Civil Engineering (building and housing) vol. 13 , no. 1 pages $89-96$.

\section{Code Books:}

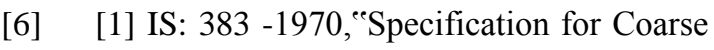
and Fine Aggregates from Natural Sources for Concrete ${ }^{e e}$, Bureau of Indian standards, New Delhi.

[7] [2] IS: 516-1959, „Methods of Tests for Strength of Concrete ${ }^{e e}$, Bureau of Indian Standards, New Delhi.

[8] [3] IS: 2386 (Part 3), „Methods of Test for Aggregate for Concrete- Specific Gravity, Density, Voids, Absorption and Bulkinge, Bureau of Indian standards, New Delhi.

[9] [4] IS: 10262- 2009, „Concrete Mix Proportioning- Guidelines ${ }^{\text {ee }}$, Bureau of Indian Standards, New Delhi. 